\title{
Effects of Livelihood Sustenance Activities on Off-Farm Income of Poultry Farmers in IMO State, Nigeria
}

\author{
Ogueri E.I ${ }^{1}$, Unaeze H.C ${ }^{2}$, Odok G.N. ${ }^{3}$, Mbah G.O ${ }^{4}$, Ugwu J.N ${ }^{5}$, Essien U.A. ${ }^{6}$, \\ Onini M.T. ${ }^{7}$, Ohajianya D.O ${ }^{6}$,
}

${ }^{1}$ Department of Agricultural Extension, Federal University of Technology Owerri, Imo State.

${ }^{2}$ Department of Agricultural Economics \& Extension, University of Portharcourt, Rivers State.

${ }^{3}$ Department of Agricultural Economics, University of Calabar, Cross River State.

${ }^{4}$ Department of Rural Sociology and Extension, Michael Okpara University of Agriculture, Umudike, Abia State, Nigeria

${ }^{5}$ Department of Agricultural Economics and Extension, Enugu State University of Science and Technology, Enugu State, Nigeria,

${ }^{6}$ Department of Agricultural Economics, Federal University of Technology Owerri, Imo State.

${ }^{7}$ Southern Ijaw Local Government Area, Oporoma, Bayelsa State.

\begin{abstract}
The study analysed the off farm income and its effect on livelihood sustenance of poultry farmers in Imo state.Multistage sampling technique was used to select 120 respondents. Data for the study were obtained with the aid of structured questionnaire and analysed using descriptive statistics and ordinary least square bivariate regression model. Results showed that: the mean off-farm income of poultry farmers was N410223 per annum. Livelihood sustenance activities of poultry farmers positively and significantly affected their off-farm income. It is recommend that government should come up policies that will center on establishment of more livelihood sustenance activities for poultry farmers that will generate increased off-farm income and promote agricultural development simultaneously.
\end{abstract}

Keywords - Income, Livelihood sustenance, Off-farm Poultry Farmers.

\section{INTRODUCTION}

In many developing countries, and particularly in Africa, agricultural income represents an essential component of rural households' subsistence. However, this type of income exhibits a high seasonality and leads to uncertain outcomes, mainly due to market prices volatility and environmental hazards. Consequently, household members partly allocate their working time to activities which provide a more stable income so as to cope with adverse shocks (Ellis, 2000).

Rural areas usually provide two categories of income sources to their dwellers; Farm and the non-farm economy. In the rural areas of Nigeria, the majority of households are involved in farm activities and many of them get their income from non-farm activities (World
Bank, 2008). Thus, in the rural area, it is hard to find peasants who do only farming.

According to (FAO, 2012), out of 3 billion people living in rural areas in the world, 2.5 billion people derive their livelihood from non-agricultural enterprises. For instance, Haggblade et al (2010) observed that non-farm income accounts for between $65 \%$ and $80 \%$ of total income of rural households in developing countries. Oxford policy management (Opm, 2004), noted that majority of households across all income strata in Nigeria are involved in several off-farm activities, whose importance has increased over the last 25 years.

In Nigeria, majority of the farm household populace either depend entirely on farming for survival and generation of income, or depend on farming to supplement their main sources of income (World Bank, 2010). Sample studies of rural income portfolios showed that on average, roughly 50 percent of rural households income in sub-Saharan African are generated from engagement in non-farm activities and transfer from urban areas or abroad, with remittance and pension payments being the chief categories of such transfer (Ellis 2000; Ellis \& Freeman, 2004). Evidence from a sample of rural villages in Tanzania (Chapmen \& Tripp, 2004; Ellis \& Madox, 2003) shows that on average, half of the household income came from crops and livestock and the other half from non-farm wage employment, selfemployment and remittance. The proportion of non-farm income was higher for the upper income groups than for the lowest income groups. Therefore, the poorest households were more reliant on agriculture, and the reliance on agriculture decreased with increased diversification into non-farm activities. 
Off-farm activities have become an important component of livelihood strategies among rural households in most developing countries. Several studies have reported a substantial and increasing share of off-farm income in total household income (Ruben and van den Berg, 2001; de Janvry and Sadoulet, 2001; Haggblade et al., 2007). Reasons for this observed income diversification include declining farm incomes and the desire to insure against agricultural production and market risks (Kijima et al., 2006; Matsumoto et al., 2006; Reardon, 1997). However, when farming becomes less profitable and more risky as a result of population growth and crop and market failures, households are pushed into off-farm activities leading to "distress-push" diversification. In other cases, however, households are rather pulled into the off-farm sector, especially when returns to off-farm employment are higher or less risky than in agriculture, resulting in "demand-pull" diversification. The study by Oseni \& Winters (2009) found that $31 \%$ of farm households in Nigeria participate in various non-farm activities and that non-farm income makes up $27 \%$ of total annual household income, on average. The authors indicated that southern households earn more from non-farm activities than northern households where about $50 \%$ of household income is from non-farm sources. According to Ibekwe et al (2010), more than $40 \%$ of the income from households in South-East Nigeria came from off farm activities. Non-farm self-employment is the most common forms of off-farm activities in Nigeria followed by non-farm wage employment (Oseni \& Winter, 2009). In a more recent study by Enyia,(2016), non farm income activities accounted for $36.4 \%$ of Fadama household income and $48.1 \%$ of non Fadama household income in Imo State, Nigeria.

A livelihood comprises capabilities, material and social resources and activities required for a means of living which also takes into account the role played by structures, policies and processes in influencing the choice of livelihood strategies by the rural poor. It is considered sustainable when it can cope with and recover from stresses and shocks, maintain or enhance its capabilities and assets, while not undermining its natural resource base (Scoones, 2000, Carney, 1998, Kanji, Macgregor \& Tacoli, 2005). A Review of different livelihood definitions, reveal that the term livelihoods is a multi-faceted concept referring to what people do to make a living with the assets at their disposal and what they accomplish by doing it in a particular context (Niehof, 2004). The concept of livelihood is therefore about individuals, households or communities making a living, attempting to meet their various consumption and economic necessities, coping with uncertainties and responding to new opportunities (de Haan and Zoomers, 2005).
The contribution of farm activities to household income in the developing world in general and Nigeria in particular is substantial. While agricultural related activities still constitute the largest share of total income among rural households, a number of empirical studies show the growing importance of Rural Non-Farm (RNF) activities in developing and transition countries. While recognizing the urgent need to maintain a robust agricultural sector, it is increasingly becoming clear that the agricultural sector alone cannot be relied upon as the core activity for rural households as a means of improving livelihood and reducing poverty. This study therefore seeks to provide an in-depth understanding of the effect of off farm income on livelihood sustenance of poultry farmers in Imo state.

The specific objectives of the study were to examine the socio economic characteristics of the poultry farmers, determine the off-farm income of poultry farmers, and determine the effects of livelihood sustenance activities on off-farm income of poultry farmers.

\section{METHODOLOGY}

This study was conducted in Imo state, Nigeria. Imo State lies between Latitude $5^{0} 10^{\prime}$ and $6^{0} 35^{\prime}$ North of the equator and between Longitude $6^{0} 35^{\prime}$ and $7^{0} 31^{\prime}$ East of the Greenwich meridian. The State has a population of about 4.13 million people (NPC, 2013). It is bounded on the East by Abia state, on the North by Anambra and Abia State, and on the West by Rivers State. The State is divided into 27 administrative units called Local Government Areas which are grouped into 3 agricultural zones viz Owerri, Okigwe and Orlu. Agriculture is the predominant occupation of the people, for almost all the farm families either as primary or secondary occupation. The ecological zone favours the growing of tree crops, roots and tubers, cereals, vegetables and nuts (Onyenwaku et al, 2010). The major crops cultivated in the state are maize, melon, rice, groundnut, vegetables, yams, cassava, oil palm, and rubber. Major animals reared include chicken, turkey, goats, sheep and pigs.

Multistage random sampling technique was used for the study. In each agricultural zone, two Local Government Areas (LGAs) were purposively selected. In each of the selected LGA, five communities were randomly selected, and from each community, one village was randomly selected to give a total of five villages. Four farmers were randomly selected from each of the villages to give a sample size of 120 poultry farmers for the study. These farmers were selected from the list of households who are into poultry production in the selected villages and this list was obtained from the Agricultural Development Programme (ADP) extension agents and Imo State Fadama III Coordination office (SFCO). Primary data were collected through the use of a set of structured questionnaire administered to the respondents. The 
primary data that were collected for the study included the socio-economic characteristics of the farmers, flock size, annual income from the farm, off-farm income, access to credit, etc. Data collected were analyzed with descriptive statistics, such as percentages, and mean, as well as ordinary least squares bivariate regression model.

The bivariate regression model as used by Rahman, 2005, Rahman \& Alamu, 2003) is implicitly specified as

$\mathrm{Y}=\mathrm{f}(\mathrm{x}, \mathrm{e})$

Where,

$\mathrm{Y}=$ Mean off-farm income (
$\mathrm{X}=$ Livelihood sustenance activities (Dummy variable, if the poultry farmer earns off-farm income from 5-9 livelihood sustenance activities $=1$, and if the poultry farmer earns off-farm income from $1-4$ livelihood sustenance activities $=0$ ).

$\mathrm{e}=$ error term.

It is expected a priori that the coefficient of $\mathrm{x}>0$.

Four functional forms of the model; linear, semi-log, double-log, and exponential were fitted to the data to select the lead equation on the basis of having the highest value of coefficient of determination $\left(\mathrm{r}^{2}\right)$, highest variable significance, and conformity to a priori expectation.

\section{RESULTS AND DISCUSSION}

The socio-economic characteristics of poultry farmers are presented in Table 1.

Table.1: Socio-economic characteristics of Poultry Farmers

Age (years) Frequency Percentage (\%) Mean

\begin{tabular}{|c|c|c|c|c|}
\hline$\overline{\leq 30}$ & 11 & 9.2 & & \\
\hline $31-40$ & 37 & 30.8 & & \\
\hline $41-50$ & 63 & & 52.5 & \\
\hline$\geq 51$ & 9 & 7.5 & & \\
\hline Total & 120 & 100 & & 41years \\
\hline \multicolumn{5}{|l|}{ Sex } \\
\hline Female & 49 & & 40.8 & \\
\hline Male & 71 & & 50.2 & \\
\hline Total & 120 & 100 & & \\
\hline
\end{tabular}

Education Level (Years)

0 (No Formal Education) 3

$1-6 \quad 16$

13.3

54.2

30.0

$13-18 \quad 36$

Total 120

100

Marital Status

Married 94

Single 26

Total

120

100

Farming Experience (Years)

$\leq 20 \quad 72$

21-30

38

$31-40$

10

Total

120

Household Size (Number of Persons)

$1-5$

47

6-10

69

$\geq 11$

4

Total

120

Extension Contact (Number of Visit/Year)

0 (No visits)

85

30

$6-10$

4

$\geq 11$

8.3

100

60.0

31.7

57.5

3.3

100

6 persons 


\begin{tabular}{|c|c|c|c|}
\hline Total & 120 & 100 & 1.0 visits \\
\hline \multicolumn{4}{|c|}{ Membership of Cooperative } \\
\hline Member & 89 & 74.2 & \\
\hline Non Member & 31 & & 25.8 \\
\hline Total & 120 & 100 & \\
\hline
\end{tabular}

Table 1 shows that majority $(52.5 \%)$ of the poultry farmers in the study area fall within the age bracket of 41 - 50 years of age with a mean age of 41 years. This implies that majority of the poultry farmers are young. The table also shows that the mean education level is 10 years. This indicates that the poultry farmers in the study area are literate enough to read and write in English language. The result indicates that mean farming experience of poultry farmers is 20.3years. The mean household size was found to be 6 persons, while mean extension contact was 1.0 visit per year. This indicates that poultry farmers are poorly visited by extension agents.

Off-farm income from livelihood sustenance activities The mean off-farm income from the poultry farmers' livelihood sustenance activities is presented in Table 2.

Table.2: Mean off-farm income from poultry farmers' livelihood sustenance activities

Livelihood sustenance Mean off-farm Percentage

activities

Interest received in cash

63482

from off-farm loan

Off-farm service earnings

(salaries, wages, pensions, etc) 106123

51446

12.5

Sale of purchased animals and animals products 73489 23112 $39546-9.6$ $33189 \quad 8.2$

Sale of fertilizers
Sale of non-agricultural items 15294

Sale of agro-chemicals

Lease of rented land

Total

*Source:
15.5

25.9
Sale of equipment

4542

3.7

$410223 \quad 100$

$4542 \quad 1.1$

Data in the table show that the mean annual off-farm income of the poultry farmer was $\$ 410223$ per annum indicating that the poultry farmers earned moderate annual off-farm income. About $26 \%$ of the off-farm income was contributed by off-farm service earnings (salaries, wages, pensions, etc), while 17.9\%, 15.5\% and $12.5 \%$ of the off-farm income were contributed by sale of purchased animals and animals products, interest received in cash from off-farm loan, and sale of purchased crop respectively. Also, 9.6\%, 8.2\%, 5.6\%, 3.7\% and $1.1 \%$ of off-farm income were from sale of fertilizers, sale of nonagricultural items, sale of equipment, sale of agro- chemicals, and lease of rented land respectively. This finding implies that off-farm income of the poultry farmers came from various livelihood sustenance activities in the study area.

Effect of Livelihood Sustenance activities of Poultry farmers on off-farm income

To determine the effect of livelihood sustenance of poultry farmers on off-farm income, four functional forms of the bivariate regression analyses were fitted to the data so as to select the lead equation. Results of the bivariate regression analyses were presented in Table 3. 
Table.3: Results of Bivariate Regression Analyses on Effect of livelihood sustenance activities of poultry farmers on off-farm income

\begin{tabular}{l} 
Explanatory variable \\
\hline Constant
\end{tabular}

Livelihood sustenance activities (x)

$$
14.247
$$

$r^{2}$

F-value

0.5531

$145.553 * *$
Linear

$\begin{array}{llll}316.112 & 287.015 & 164.009 & 121.318\end{array}$

3.069

$(4.677)^{* *}$

0.082

Double-log

Exponential

$109.58 * *$

0.4821
0.8934

$992.667 * *$
0.007

$(2.549)^{*}$

0.6924 $266.308 * *$

Sample size (n) 120 120 120

Figures in parentheses are t-ratios

* Significant at 5\%

** Significant at $1 \%$

Source: Survey Data, 2016

The table shows that the double-log function produced the highest value of coefficient of determination $\left(r^{2}\right)$, highest variable significance, and conformed to a priori expectation and was therefore selected as the lead equation and used for discussion.

The value of $\mathrm{r}^{2}$ was 0.8934 , which implies that about $89 \%$ of the variation in off-farm income was accounted for by the action of poultry farmers livelihood sustenance activities.

The $\mathrm{r}^{2}$ value of 0.8934 gave F-value of 992.667 which was significant at $1 \%$ level of probability, implying that the double-log function gave a good fit to the data.

The coefficient of livelihood sustenance activities ( $x$ ) was positive and significant at $1 \%$ level, implying that increase in livelihood sustenance activities employed by the poultry farmers lead to increase in off-farm income. Therefore, there was a positive effect of poultry farmers' livelihood sustenance activities on their off-farm income in Imo State, Nigeria.

\section{CONCLUSION AND RECOMMENDATIONS}

The mean off-farm income earned by poultry farmers was \#10223. Livelihood sustenance activities of poultry farmers positively and significantly affected their off-farm income. The study recommends that government should come up with policies that will center on establishment of more livelihood sustenance activities for poultry farmers that will generate increased off-farm income and promote agricultural development simultaneously.

\section{REFERENCES}

[1] Carney, D. (1998). Implementing the sustainable livelihood approach. "In D. Carney eds., Sustainable Rural Livelihoods: What Contribution Can We Make. London: DFID. 143
[2] De Hann, L.J., \& Annelies Z. (2005). Exploring the Frontier of livelihood research. Development and Change, 36 (1): 27-47.

[3] De Janvry, A., Sadoulet, E., \& Murgai, R. (2002). Rural development and rural policy. In: B.L. Gardner and G.C. Rausser (ed.). Handbook of Agricultural Economics. 1593-1658. Amsterdam: Elsevier. Retrieved October 11, 2013 from mpra.ub.uni-muenchen.de/13365

[4] Ellis, F. (2000). Rural Livelihood Diversity in Developing Countries: Analysis, Methods, Policy, Oxford: Oxford University Press.

[5] Ellis, F., \& Freeman, H. A. (2004). Rural Livelihoods and Poverty Reduction Strategies in Four African Countries, Journal of Development Studies, 40(4):18-23.

[6] Ellis, F. \& Mdoe, N. (2003). Livelihoods and Rural Poverty Reduction in Tanzania, World Development, 31(8):1367-1384.

[7] Enyia C.O (2016), Livelihood diversification Strategies among Fadama and non Fadama users in Imo State, Nigeria. An unpublished Ph.D thesis, Federal University of Technology Owerri.

[8] Food and Agriculture Organisation,(2012). Livelihood Diversification and Natural Resource Access: Livelihood Support Programme; Working Paper No. 9; Food and Agriculture Organisation. Retrieved December 4, 2015 from ttp:www.fao.org /DOCREP/006/ AD689E/AD689E00.

[9] Haggblade, S., Hazell, P., \& Reardon, T., (2007). "Introduction", in Haggblade, S, P. Hazell, and T. Reardon, (Eds), Transforming the Rural Nonfarm Economy, Baltimore, Johns Hopkins University Press.

[10] Ibekwe, U. C, Eze C.C, Ohajianya, D.O, Orebiyi J.S, Onyemauwa, C.S., \& Korie, O. C. (2010). Determinants of non farm income among farm 
households in South East Nigeria. Academia Area, 2010; 2(8): 29-33.

[11] Kanji, N., Macgregor, J. \& Tacoli, C. (2005).'Understanding market-based livelihoods in a globalizing world: combining approaches and methods'. London: International Institute for Environment and Development (IIED).

[12] Niehof, A. (2004). The significance of diversification for rural livelihood systems. J. Food Policy. 29(4): pp.321-338. Retrieved October 23, 2013 from http://www.sciencedirect.com /science/article/B6VCB-4DBSWD2

[13] National Population Commission (2013): National Population Commission updated population figure for Imo State of Nigeria 2013 census report. http://www.qts nigeria.com/.

[14] Onyenweaku, C E, \& Nwachukwu, I.N. (2010). Productivity growth in food crop production in Imo State, Nigeria. African Crop Science Journal, 18(3):89-95

[15] OPM (2004). Oxford Policy Management, DFID Rural and Urban Development Case Study Nigeria. June 2004.

[16] Oseni, G. \& Winters, P. (2009). Rural Nonfarm Activities and Agricultural Crop Production in Nigeria. Agricultural Economics, 40(2), 189-201

[17] Reardon, T. (2007). Agribusiness transitions in the Developing World. Chapter 5 in Haggblade, Hazell and Reardon (eds), The Rural Nonfarm Economy: Opportunities and Threats in the Developing World. Baltimore: Johns Hopkins University Press.

[18] Ruben, R., Van Der Berg, M. (2001): Nonfarm employment and rural farm households in Honduras. World Development 29(3):549-560.

[19] Scoones, I., (2000). Sustainable Rural Livelihoods: A framework for analysis. IDS Working Paper 72. Institute of Development Studies.

[20] World Bank (2008). World Development Report 2008 Overview: Agriculture for development. Washington DC: International Bank for Reconstruction and Development/World Bank

[21] World Bank (2010): World Bank updates poverty estimates for developing World. Retrieved December 3, 2015 from http://econ.worldbank.org/. 